\title{
Wickerhamomyces patagonicus sp. nov., an ascomycetous yeast species from Patagonia, Argentina
}

\author{
Correspondence \\ Virginia de García \\ vdegarcia@crub.uncoma.edu.ar \\ vikidegarcia@yahoo.com.ar
}

\author{
Virginia de García, ${ }^{1}$ Silvia Brizzio, ${ }^{1}$ Diego Libkind, ${ }^{1}$ Carlos A. Rosa ${ }^{2}$ \\ and María van Broock ${ }^{1}$
}
${ }^{1}$ Laboratorio de Microbiología Aplicada y Biotecnología, Centro Regional Universitario Bariloche, Universidad Nacional del Comahue, Argentina
${ }^{2}$ Departamento de Microbiologia, ICB, C.P. 486, Universidade Federal de Minas Gerais, Belo Horizonte, MG, 31270-901, Brazil

\begin{abstract}
Eight strains of a novel yeast species were isolated from tree saps of 'Coihue' (Nothofagus dombeyi, Nothofagaceae) and glacial meltwater (Castaño Overo River) in the Nahuel Huapi National Park, Patagonia, Argentina. The sequences of the D1/D2 domains of the large subunit of the rRNA gene showed that this novel yeast species belongs to the Wickerhamomyces genus (Order Saccharomycetales, Family Wickerhamomycetaceae). The closest related species were Candida ponderosae and Wickerhamomyces chambardii. Wickerhamomyces patagonicus sp. nov. is proposed to accommodate these novel strains, with the type strain CRUB $1724^{\top}$ (=CBS $11398^{\top}=$ JCM $16381^{\top}$ ).
\end{abstract}

The diversity of ascomycetous yeasts in pristine environments, such as those found in the Nahuel Huapi National Park (NHNP) in north-western Patagonia (Argentina), has not yet been fully explored. This park has a cold to temperate climate, and includes vast areas with little or no human influence. So far, studies on the occurrence of yeasts in aquatic and terrestrial environments in the NHNP have characterized native yeast communities and described several novel species (Brizzio \& van Broock, 1998; de García et al., 2007; Libkind et al., 2003, 2005, 2007, 2008, 2009). However, these studies have focused mainly on basidiomycetous yeasts of aquatic environments.

Analysis of the sequences of the D1/D2 domains of the large-subunit rRNA gene of eight yeast isolates, from natural environments, showed that these strains represent a novel yeast species of the genus Wickerhamomyces. This novel species was related to Candida ponderosae and Wickerhamomyces chambardii. In this paper, we describe this novel species as Wickerhamomyces patagonicus sp. nov.

Seven strains of $W$. patagonicus sp. nov. were recovered from two different sap exudates on two cut branches of one tree of Nothofagus dombeyi in the pathway of the Frias Glacier in the NHNP, February 2007. The sap found on N.

Abbreviations: ITS, internal transcribed spacer; MSP-PCR, microsatellite-primed PCR; NHNP, Nahuel Huapi National Park.

The GenBank/EMBL/DDBJ accession numbers for the 26S rRNA gene D1/D2 domain sequences of strains CRUB $1724^{\top}$ and CRUB 1219 are FJ666399 and FJ952145, respectively, and for the ITS sequence of strain CRUB $1724^{\top}$ FJ793131. dombeyi was bright beige and translucent with some turbidity due to the presence of microbial growth. Exudates were collected in the forest that surrounds Mount Tronador in sterile plastic plates; the samples were serially diluted, stirred with a sterile loop and streaked onto YM agar ( $1 \%$ glucose, $0.5 \%$ peptone, $0.3 \%$ malt extract, $0.3 \%$ yeast extract, $2 \%$ agar) containing $100 \mathrm{mg}$ chloramphenicol $1^{-1}$. The YM plates were incubated at room temperature $\left(20 \pm 2{ }^{\circ} \mathrm{C}\right)$ for 3 to 8 days. Yeast strains were purified and maintained on potato dextrose agar slants (Yarrow, 1998). An additional yeast isolate of the novel species was recovered from a meltwater river, originating from the Castaño Overo glacier of Mount Tronador, as described by de García et al. (2007). This glacial meltwater river runs through the Nothofagus forest where the other seven samples were obtained. The strains considered in this study are listed in Table 1.

The isolates were characterized morphologically and physiologically according to Yarrow (1998). Ascospore production was observed after growth on glucose-yeast extract (GY; $0.2 \%$ glucose, $0.1 \%$ yeast extract, $2 \%$ agar) at $18{ }^{\circ} \mathrm{C}$ for 3 weeks. For PCR fingerprinting, the microsatellite-primed PCR (MSP-PCR) technique was applied (Libkind et al., 2003). Protocols for DNA extraction, primers, PCR and electrophoresis conditions were as described by Libkind et al. (2003). For sequencing of 26S rRNA gene D1/D2 domains, forward primer NL1 (5-GCATATCAATAAGCGGAGGAAAAG-3) and reverse primer NL4 (5-GGTCCGTGTTTCAAGACGG-3) were employed. The internal transcribed spacer (ITS) region 
Table 1. List of isolates of Wickerhamomyces patagonicus sp. nov.

CRUB, Regional University Center of Bariloche (Centro Regional Universitario Bariloche). CBS, Centraalbureau voor Schimmelcultures the Netherlands; JCM, Japan Collection of Micro-organisms.

\begin{tabular}{|lll|}
\hline Source & \multicolumn{1}{c|}{ Location } & Strains \\
\hline Exudates of Nothofagus dombeyi (Coihue, & Pathway to Frias Glacier, Mount & CRUB 1724 $\left(=4^{\mathrm{T}}\right.$ CBS 11398 $\left.{ }^{\mathrm{T}}=\mathrm{JCM} \mathrm{1638}^{\mathrm{T}}\right)$, CRUB 1723, \\
Nothofagaceae) & Tronador, NHNP, Patagonia, & CRUB 1725, CRUB 1726, CRUB 1727, CRUB 1728, \\
& Argentina & CRUB 1729 \\
Meltwater of Castaño Overo River & Castaño Overo Glacier & CRUB 1219 \\
& & \\
\hline
\end{tabular}

was sequenced using the forward primer ITS1 (5TCCGTAGGTGAACCTGCGG-3) and the reverse primer ITS4 (5-TCCTCCGCTTATTGATATGC-3). Sequencing was carried out using an ET Dynamic Terminator kit in a MegaBACE 1000 automated 96 capillary DNA sequencer (GE Healthcare). The nucleotide sequences and other related sequences were multiply aligned using the CLUSTAL W software package (EMBL-EBI; http://www.ebi.ac.uk/ clustalw/). Phylogenetic relationships were estimated by using MEGA version 4.0.2 (Tamura et al. 2007); a phylogenetic tree was reconstructed using the neighbour- joining algorithm, and bootstrap values were calculated from 1000 replicate runs. The Kimura two-parameter model was used to estimate evolutionary distance.

\section{Classification, ecology and species delineation}

Results of MSP-PCR fingerprinting characterization for all eight strains showed no differences in DNA banding patterns (data not shown). Sequence analysis of the D1/D2 region of the large-subunit rRNA gene of strains CRUB $1724^{\mathrm{T}}$ and CRUB 1219 placed these strains in the recently

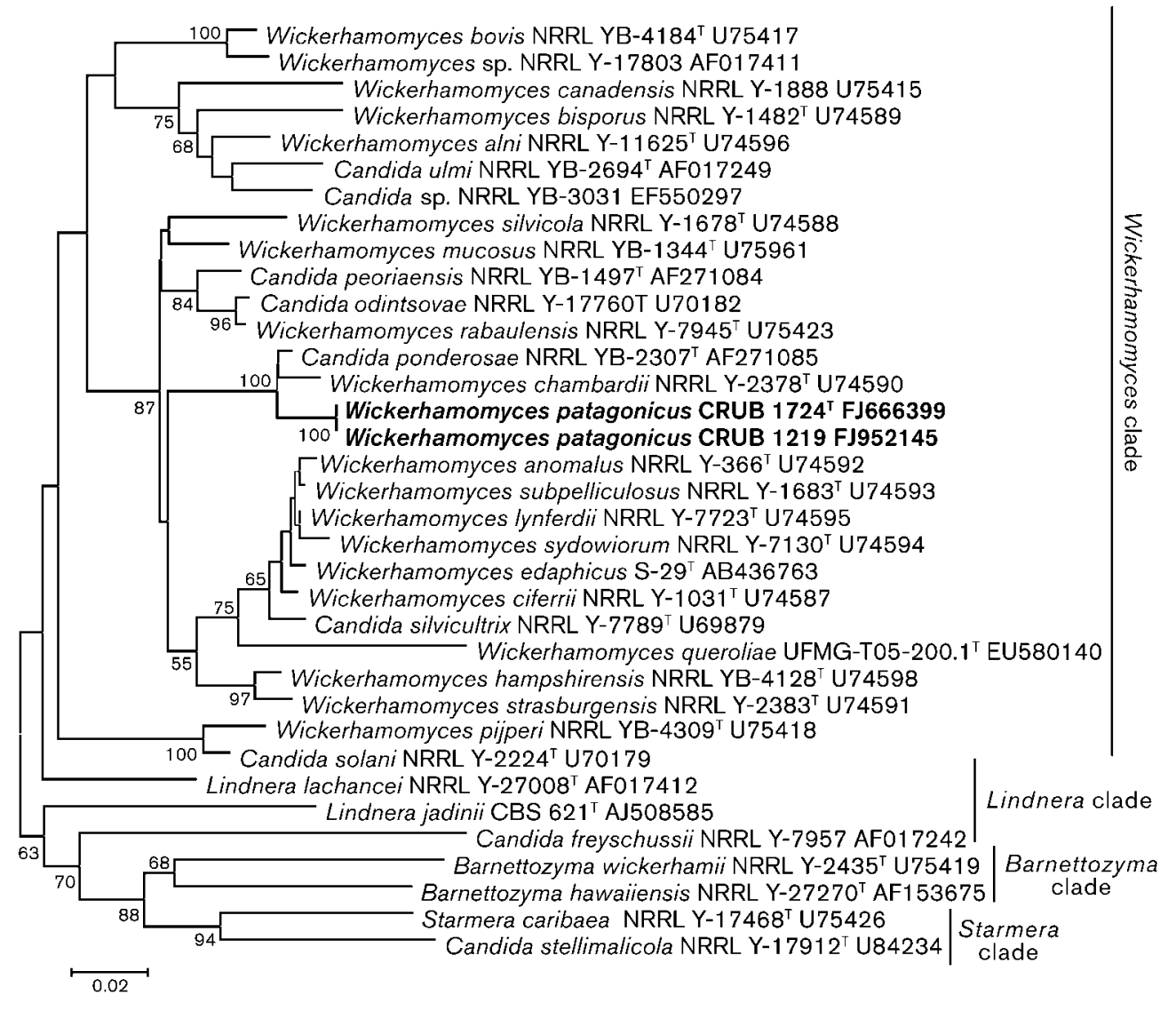

Fig. 1. Phylogenetic placement of Wickerhamomyces patagonicus sp. nov. obtained by neighbour-joining (distance K2P method) of the D1/D2 domains of the large subunit of the rRNA gene. Bar, number of substitutions accumulated every 100 nucleotides. Boostrap values higher than $50 \%$ are shown (1000 replicates). 
proposed genus Wickerhamomyces (Kurtzman et al., 2008). The novel strains differed by nine nucleotide substitutions $(1.5 \%)$ from $C$. ponderosae, and by 13 nucleotide substitutions (2.2\%) from $W$. chambardii (Fig. 1). ITS sequence analysis showed that strain CRUB $1724^{\mathrm{T}}$ differed by 14 nucleotide substitutions $(2.4 \%)$ from $C$. ponderosae and by 37 nucleotide substitutions (6.4\%) from $W$. chambardii. The phenotypic profile of this novel species fitted the genus description proposed by Kurtzman et al. (2008). Hat-shaped ascospores were produced, and methanol and hexadecane were not assimilated. This evidence allowed the designation of these strains as a novel species in the Wickerhamomyces clade, according to criteria proposed by Kurtzman et al. (2008). We named this novel species Wickerhamomyces patagonicus, with the type strain CRUB $1724^{\mathrm{T}}$.

The physiological profiles of $W$. patagonicus sp. nov., $C$. ponderosae and W. chambardii were markedly different. $W$. patagonicus sp. nov. showed positive growth on vitaminfree medium while $C$. ponderosae and $W$. chambardii could not grow in this substrate. Separation of $W$. patagonicus sp. nov. from C. ponderosae could be based on growth on Dmannitol and citrate, which are positive for $C$. ponderosae and negative for the novel species. W. chambardii cannot grow, on D-xylose or lysine while $W$. patagonicus sp. nov. gives positive responses for these physiological tests (Table 2). Single colonies of $W$. patagonicus sp nov. were

Table 2. Salient physiological differences between Wickerhamomyces patagonicus sp. nov., Candida ponderosae and Wickerhamomyces chambardii

Species: 1, Wickerhamomyces patagonicus sp. nov.; 2, Candida ponderosae; 3, W. chambardii. -, Negative; +, positive; w, weak; V, variable.

\begin{tabular}{|lccc|}
\hline Physiological test & $\mathbf{1}$ & $\mathbf{2}$ & $\mathbf{3}$ \\
\hline Galactose & $\mathrm{W}$ & + & + \\
Raffinose & $\mathrm{W}$ & - & - \\
Cellobiose & $\mathrm{W}$ & + & + \\
Soluble starch & $\mathrm{W}$ & - & - \\
D-Xylose & + & + & - \\
L-Rhamnose & + & - & - \\
N-Acetyl-D-glucosamine & $\mathrm{W}$ & - & - \\
D-Mannitol & - & + & - \\
D-Glucitol & $\mathrm{W}$ & - & - \\
Salicin & $\mathrm{W}$ & + & + \\
DL-Lactate & $\mathrm{W}$ & + & + \\
Citrate & - & + & $\mathrm{V}$ \\
Propane-1,2-diol & - & - & $\mathrm{w}, \mathrm{V}$ \\
Nitrite & $\mathrm{w}$ & - & - \\
Lysine & + & + & - \\
Vitamin-free medium & + & - & - \\
\end{tabular}

able to produce two to four hat-shaped ascospores when growing on GY agar.

Some studies reporting yeasts associated with trees of the species Nothofagus have been reported (Ramirez \& González, 1984; Serjeant et al., 2008), but none of the isolates were obtained from exudates. In this paper, we suggest that $W$. patagonicus sp. nov. is associated with the Nothofagus dombeyi exudates. Its presence in the glacial meltwater river may be attributed to surface run-off from the surrounding Nothofagus forest. Species related to $W$. patagonicus sp. nov. have been isolated from tree-related systems. C. ponderosae was obtained from the frass of an unidentified beetle in Ponderosa pine in the USA, and $W$. chambardii from a banana cultivar in Indonesia (Kurtzman, 2001; Nakase et al., 2006), which could suggest that these yeasts are associated with trees, and that probably the insects that visit these substrates are vectors for these species.

\section{Latin diagnosis of Wickerhamomyces patagonicus de García, Brizzio, Rosa, Libkind et van Broock sp. nov.}

Cultura in agaro malti post dies $2\left(20{ }^{\circ} \mathrm{C}\right)$ parva, convexa, glabra et candida. In agaro farinae Zea mays post dies 14 mycelium ner pseudomycelium non formantur. Species homothallica. Asci inconjugati et stabiles, et habentes 2-4 ascosporae petasiformes. Glucosum non fermentantur. Glucosum, D-galactosum (exigue), D-xylosum, L-rhamnosum, cellobiosum (exigue), salicinum (exigue), raffinosum (exigue), amylum solubile (exigue), glucitolum (exigue), glycerolum, xylitolum, acidum lacticum (exigue), $\mathrm{N}$ acetylglucosaminum (exigue), acidum succinicum, ethanolum et ethyl acetas assimilantur, at non L-sorbosum, Dglucosaminum, D-ribosum, L-arabinosum, D-arabinosum, maltosum, trehalosum, melibiosum, lactosum, melezitosum, inulinum erythritolum, ribitolum, mannitolum, galactitolum, meso-inositolum, gluconatum, acidum citricum, methanolum, hexadecanum, acetonum et 2-propanolum. Lysinum et natrium nitrosum assimilantur. Ad crescentiam vitamina externae non necessariae. $25{ }^{\circ} \mathrm{C}$ crescit neque $37^{\circ} \mathrm{C}$. In media cum $15 \% \mathrm{NaCl}$, cum $1 \%$ acido acetico aut cum $50 \%$ glucose non crescit. Materia amyloidea iodophila non formantur. Typus CRUB $1724^{\mathrm{T}}$. In collectione zymotica Centraalbureau voor Schimmelcultures, Trajectum ad Rhenum, sub no. CBS $11398^{\mathrm{T}}$ typus stirps deposita est.

\section{Description of Wickerhamomyces patagonicus de García, Brizzio, Rosa, Libkind and van Broock sp. nov.}

Wickerhamomyces patagonicus (pa.ta.go'ni.cus. N.L. masc. adj. patagonicus referring to Patagonia, the region from where the species was isolated).

Growth on $5 \%$ malt extract agar. After 3 days on $5 \%$ malt extract agar at $20{ }^{\circ} \mathrm{C}$, cells are ovoid, single or in pairs. Budding is multilateral. After 2 days on YM agar at $20{ }^{\circ} \mathrm{C}$, 
colonies are white, smooth and glistening. In Dalmau plates after 2 weeks on cornmeal agar, pseudomycelium or true mycelium is not formed. The species is homothallic. After 5 days on glucose-yeast extract agar, cells give rise to deliquescent asci containing two to four hat-shaped ascospores (Fig. 2). Glucose is not fermented. Assimilates the following carbon compounds: glucose, D-galactose (weakly), D-xylose, L-rhamnose, cellobiose (w), salicin (w), raffinose $(\mathrm{w})$, soluble starch $(\mathrm{w})$, D-glucitol $(\mathrm{w})$, glycerol, xylitol, DL-lactate (w), $N$-acetyl-D-glucosamine (w), succinate, ethanol and ethylacetate. No growth occurs on Lsorbose, D-glucosamine, D-ribose, L-arabinose, D-arabinose, maltose, $\alpha, \alpha$-trehalose, melibiose, lactose, melezitose, inulin, meso-erythritol, ribitol, D-mannitol, galactitol, myo-inositol, D-gluconate, citrate, methanol, hexadecane, acetone or 2-propanol. Assimilates the following nitrogen compounds: lysine and nitrite (w). Growth at $37^{\circ} \mathrm{C}$ is negative. Growth in vitamin-free medium is positive. Growth on YM agar with $10 \%$ sodium chloride is negative. Growth on $50 \%$ glucose/yeast extract $(0.5 \%)$ is negative. Starch-like compounds are not produced. In $100 \mu \mathrm{g}$ cycloheximide $\mathrm{ml}^{-1}$ growth is negative. Urease activity is negative. Diazonium Blue B reaction is negative.

W. patagonicus was isolated from exudates of 'Coihue' (Nothofagus dombeyi, Nothofagaceae), and a meltwater river of the Castaño Overo glacier in Nahuel Huapi National Park, Patagonia, Argentina. The type strain is CRUB $1724^{\mathrm{T}}\left(=\right.$ CBS $11398^{\mathrm{T}}=$ JCM $\left.16381^{\mathrm{T}}\right)$.

\section{Acknowledgements}

This work was accomplished with financial aid from the Universidad Nacional del Comahue (project B143), Consejo Nacional de Investigaciones Científicas y Tecnológicas, CONICET (PhD fellowship given to V.d.G. and project PIP 6536), Agencia Nacional de Investigaciones Científicas, ANPCyT (projects PICT04-22200 and PICT06-1176) and SECYT-CAPES bilateral cooperation agreement financially supporting cooperation between Argentina and Brazil (cooperation project PROSUL ASCIN/CNPq 490430/2008-2). We

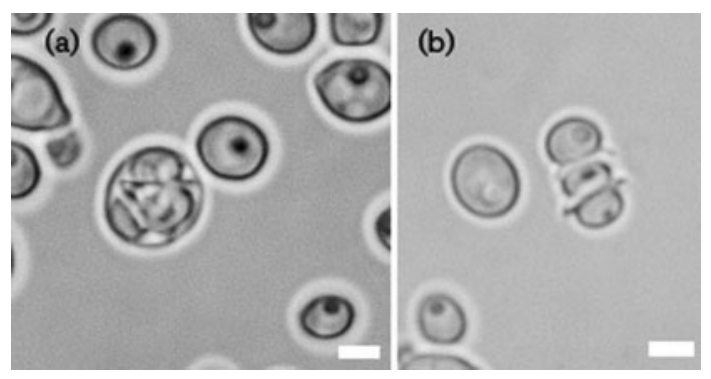

Fig. 2. Phase-contrast micrograph of strain CRUB $1724^{\top}$ on GY agar after 5 days at $22^{\circ} \mathrm{C}$. (a) Cells and an ascus with hat-shaped ascospores; (b) budding cells and three released hat-shaped ascospores. Bar, $5 \mu \mathrm{m}$. would like to thank the authorities of Parques Nacionales (Argentina) for providing permission for water sample collection within the NHNP.

\section{References}

Brizzio, S. \& van Broock, M. (1998). Characteristics of wild yeast killer from Nahuel Huapi National Park (Patagonia, Argentina). Food Biotechnol 36, 273-278.

de Garcia, V., Brizzio, S., Libkind, D., Buzzini, P. \& van Broock, M. R. (2007). Biodiversity of cold-adapted yeasts from glacial meltwater rivers in Patagonia, Argentina. FEMS Microbiol Ecol 59, 331-341.

Kurtzman, C. P. (2001). Four new Candida species from geographically diverse locations. Antonie van Leeuwenhoek 79, 353-361.

Kurtzman, C. P., Robnett, C. J. \& Basehoar-Powers, E. (2008). Phylogenetic relationships among species of Pichia, Issatchenkia and Williopsis determined from multigene sequence analysis, and the proposal of Barnettozyma gen. nov., Lindnera gen. nov. and Wickerhamomyces gen. nov. FEMS Yeast Res 8, 939-954.

Libkind, D., Brizzio, S., Ruffini, A., Gadanho, M., van Broock, M. R. \& Sampaio, J. P. (2003). Molecular characterization of carotenogenic yeasts from aquatic environments in Patagonia, Argentina. Antonie van Leeuwenhoek 84, 313-322.

Libkind, D., Gadanho, M., van Broock, M. R. \& Sampaio, J. P. (2005). Sporidiobolus longiusculus sp. nov. and Sporobolomyces patagonicus sp. nov., two new members of the Sporidiobolales isolated from aquatic environments in Patagonia, Argentina. Int J Syst Evol Microbiol 55, 503-509.

Libkind, D., Ruffini, A., van Broock, M., Alves, L. \& Sampaio, J. P. (2007). Biogeography, host specificity, and molecular phylogeny of the basidiomycetous yeast Phaffia rhodozyma and its sexual form, Xantophyllomyces dendrorhous. Appl Environ Microbiol 73, 11201125.

Libkind, D., Gadanho, M., van Broock, M. R. \& Sampaio, J. P. (2008). Studies on the heterogeneity of the carotenogenic yeast Rhodotorula mucilaginosa from Patagonia, Argentina. J Basic Microbiol 48, 9398.

Libkind, D., Gadanho, M., van Broock, M. \& Sampaio, J. P. (2009). Cystofilobasidium lacus-mascardii sp. nov., a new basidiomycetous yeast species isolated from aquatic environments of the Patagonian Andes and Cystofilobasidium macerans sp. nov., the sexual stage of Cryptococcus macerans. Int J Syst Evol Microbiol 59, 622-630.

Nakase, T., Jindamorakot, S., Am-in, S. \& Tanticharoen, M. (2006). Yeast biodiversity in tropical forests of Asia. In The Yeast Handbook: Biodiversity and Ecophysiology of Yeasts, chapter 17, pp. 441-460. Edited by C. A. Rosa \& G. Péter. Berlin: Springer.

Ramírez, C. \& González, A. (1984). Two new species and one variety of nitrate-utilizing mycelial Candida isolated from decayed wood in the evergreen rainy Valdivian forest of southern Chile. Mycopathologia 88, 55-60.

Serjeant, K., Tang, R., Anfang, N., Beggs, J. R. \& Goddard, M. R. (2008). Yeasts associated with the New Zealand Nothofagus honeydew system. N Z J Ecol 32, 209-213.

Tamura, K., Dudley, J., Nei, M. \& Kumar, S. (2007). MEGA4: molecular evolutionary genetics analysis (MEGA) software version 4.0. Mol Biol Evol 24, 1596-1599.

Yarrow, D. (1998). Methods for the isolation, maintenance and identification of yeasts. In The Yeasts, a Taxonomic Study, 4th edn, pp. 77-100. Edited by C. P. Kurtzman \& J. W. Fell. Amsterdam: Elsevier. 